\title{
Malaysia's Green Neighbourhood Initiatives: Implementing and Approach in Putrajaya, Selangor and Johor
}

\author{
Rohana Ramli, Dasimah Omar, Puziah Ahmad
}

\begin{abstract}
Green neighborhood is a neighborhood that practices a way of life to meet the needs of people's activities. Green neighbourhoods can form friendships, practice agricultural areas, use renewable energy methods and maintain sensitive nature. This practice also makes easy access to home, workplace, infrastructure, public utilities, transit facilities and easily accessible in neighbourhood. Conflicts between rapid development and communities required a new paradigm to understand about the relationships between green neighbourhood and communities. The objectives of the paper are to study the implementation of green neighbourhood initiatives in Putrajaya, Selangor and Johor and to determine their element of sustainability in the green action plans. The action plans and programs by local authorities in green neighbourhood initiative was summarised in a framework. The methodology of study base on document analysis which related to the green city and neighbourhood initiatives conducted by the study area is summarised in the tabulation of action or program. Based on the result's analysis, it indicated each study area has created its own approaches and strategies of sustainability by adopting impressive programs and strategies such as implementing pedestrian walkway, bicycle lane, community farming, rainwater harvesting, composting and others. The action and program in green neighbourhood and green city by the local authorities are their commitment to social, economic and environment. Local Authorities and the private agencies can contribute their commitment in order to implement green neighbourhood with having a comprehensive action plan. In conclusion green neighbourhood implementation in Putrajaya, Johor and Selangor practices as an action for the present and future development.
\end{abstract}

\section{Keywords: Green Neighbourhood; Sustainable; Community}

\section{INTRODUCTION}

Highlight In recent years, sustainability of urban development has been characterized as a development that can cater to the needs of today's development without affecting the capabilities of development and future generations to meet their own needs. In et al., (2016) mentioned development for sustainability must consider the future generation. Faridah S. et al. (2006) mentioned sustainable development can improve the human quality of life and living for preserve supporting environment.

Revised Manuscript Received on April 19, 2019.

Rohana Ramli, PhD Student, Built Environment, Depatment in Town and Regional Planning, Faculty of Architecture, Planning \& Surveying, Universiti Teknologi MARA (UiTM), Shah Alam, Malaysia. (Email: rohanaramliuitm@gmail.com)

Dasimah Omar, Lecturer, Depatment in Town and Regional Planning, Faculty of Architecture, Planning \& Surveying, Universiti Teknologi MARA, Shah Alam, Malaysia. (Email: dasimaho@yahoo.com)

Puziah Ahmad, Lecturer, Depatment in Town and Regional Planning, Faculty of Architecture, Planning \& Surveying, Universiti Teknologi MARA, Shah Alam, Malaysia. (Email: puziah.ahmad114@gmail.com)
Development for element of sustainable must consider three main components which are social, economic and environmental aspects. Wahi Mohamad \& Zin (2018) has mentioned since the United Nations Conference on the global agenda and the Human Environment in 1972, Malaysia has taken serious steps in addressing environmental issues and issues. In 1992, Malaysia also demonstrated its commitment to the Rio Summit afterwards the Malaysian Nature Environment. Sustainable and Environmental issues are undoubtedly the challenge of the $21^{\text {st }}$ century. The current global climate change brings the need to serious in designing urban development. Cities now find themselves in the middle of the 'Green Revolution' as one of the most important development components to do sustainability. Some of the innovations and city initiatives meant to make the city more sustainable, greener, healthier and environmentally friendly. One of the concepts that has introduced for sustainable city formation is the Green Neighbourhood Initiative. This initiative is the first attempt to join the principles of urban sustainability with the level of community development at a micro level. Green neighbourhood initiatives designated using various indicators that go beyond traditional variables such as community farming, waste composting, pedestrian walkway, bicycle lane, plant protection, convenience, energy conservation and park size. In the Tenth Malaysia Plan, the emphasis was on the formation of a vibrant, compressible and vibrant city, green technology development and green building, which is part of the green neighbourhood in urban living.

Lack of awareness about the importance of preserving the environment from stakeholders and communities. The World Bank (2018) mentions around the world, waste generation rates are rising. In 2012, people in the world's cities produce 1.3 billion tons of solid waste annually with an estimated 1.2 kilograms per day. By 2025, with the growing population growth and rapid urbanization, municipal waste generation expected to increase to 2.2 billion tonnes. The waste managed will contribute as a breeding ground for disease vectors, contributing to global climate change through methane generation and promoting urban violence.

Zakaria, R. et al. (2012) mentioned that the plan preparation shall be improved to be more comprehensive in applying the sustainability concept. 
The neighbourhood elements which is scattered in few departments guideline did not coordinated well and this makes the implementation stage even tougher. There were no single guidelines that can solve the problem in current practice. The need for the a proper guideline that can include all the neighbourhood elements into one guideline need to be set up so that the reference can be evenly followed by all level planners whether in federal, state or local level. According to Town Planning Department, Subang Jaya Municipal Council (2019), lack of implementation in green neighbourhood initiatives program by local authority in order to give understanding and awareness of community for participation in the green neighbourhood initiatives program. Zulkifli, N. (2017) mentioned local agenda in Malaysia has been introduced since 1999 and nowadays, in local authorities in Malaysia still in the process of implementation.

\section{A. Aim and Objectives}

The purpose of this paper are to study the implementation of green neighbourhood initiatives in Putrajaya, Selangor and Johor. The objectives to determine their element of sustainability in the green action plans with actions and programs of state government and Local Authorities in implementing green neighbourhood initiatives for urban living.

\section{THEORETICAL}

\section{A. Profile of Malaysian Sustainable Development Stage}

The sustainable development programs in Malaysia towards green environment was established in the Third Malaysian Plan (1976-1980). Heritage conservation is the most important focus in development in Malaysia. This conservation also gives emphasis to population growth and other developmental growth, especially the industry. In the Fifth Malaysia Plan (1986-1990), environmental protection is a key agenda within the framework of national development. Environmental conservation measures are to sustain forest, tourism and physical development.

The eighth Malaysia Plan, development towards the environment continues. Sectarian control and planning is still ongoing in the Ninth Malaysia Plan (2006 - 2010). The 11th Malaysia Plan still focuses on green development and sustainable development. Sustainable and sustainable development agenda continues to maintain the quality of the environment, the day and the future development. Malaysia's five-year plan is a good move from the government to maintain sustainable township.

Referring to the Advanced Index Sustainable Development Goals (2018), the index score for SDG for the whole of 2018 was 708, Malaysia was ranked second in Asian and ranked 55th out of 156 countries. This data shows Malaysia's position is lower than China and eight higher levels than Russia. Malaysia has stepped up its determination to continue its journey towards sustainable development more aggressively through the agenda of 2030. Additionally, Malaysia has taken a positive step towards implementing SDG principles by taking this proactive step in the 11th Malaysia Plan by prioritizing the SDG in all aspects of development Malaysia. High achievement in implementing all SGD principles is a major goal for Malaysia.

\section{B. Green Neighbourhood Initiatives}

Referring to PLANMalaysia (2012), green neighbourhood guideline as guidance to developers and Local Authorities on the elements that should include in developing green neighbourhood initiatives. It is initiatives include walkability and connectivity, creating a transit facility in the near distance, green network, mixed-use development, high density, neighbourhoods safe environment, application of green technology in building construction and infrastructure facilities, selection and planning of neighbourhoods community networks. Work together by the Local Authorities with all the local community is the important way to success as mentioned by Ismail R, Saat S.A. (2004). The green plan and programs considered with various action in order to implementing green neighbourhood since this initiatives was introduced in Malaysia. In this regard, an important approach is required at the council and city level to implement services that facilitate intermediation between competing pressures for development of economic, protection for environment and a more benefits for society. This green neighbourhood action and initiative is a major innovation in realizing local planning towards addressing the concept of sustainable development. According to Dahlia et al. (2013) the green neighbourhood and green community based approach could not be rectified without supporting input from local community.

\section{Malaysian Green Neighbourhood Action Plan}

According to the Ministry of Urban Wellbeing, Housing and Local Government (2012), the awareness and success of this green neighbourhood action plan requires support from stakeholders, Local Authorities, developers, urban planners, engineers, landscapes, environmental officers, architects and agencies related public and private sectors. The combination of all the expertise of various professional, agency and related bodies can provide the best planning in implementing this green neighbourhood initiative. Communities are also encouraged to welcome the government's efforts in this sustainable manner so that they can be wholesome in economic and environmental aspects. Based on Dahlia et al (2013), the guidelines and action have been taken to assist local authorities and agencies to implement five (5) green neighbourhood initiatives selected as pedestrian paths, bicycle lanes, rainwater harvesting systems, compost waste and community agriculture. These five actions are given priority as it can be implemented with a quick and easy and cheaper time. These initiatives can be practiced every day because it does not take long. Most of these green neighbourhood activities are the everyday practice of the community for example to work, gardening, storing rainwater and making compost fertilizers.

D. Implementation and Approach of Green Neighbourhood Initiative 


\section{i.. Putrajaya}

Putrajaya is a Federal Government Administrative Center in Peninsular Malaysia. The total area of Putrajaya is about $32 \mathrm{~km}^{2}(8,000$ acres) and the total population estimated of 91,900 people. Putrajaya has also been planned with the theme of two main aspects, namely, a smart city and a city within the park. Putrajaya is a free-to-town municipality that places government emperors working in government. Putrajaya is a municipal area that also has government institutions with various government departments in it. The main land use of Putrajaya is also a lake, green area, housing, business and community facilities provided. Sabeen Qureshi and Ho Chin Siong (2011), stated that the concept of urban conservation in the park is very clear with almost $40 \%$ of the total area of Putrajaya area of 4,931 hectares specifically for green areas, recreational areas and open spaces. The area of green and recreation is in line with the established Putrajaya Master Plan. With the estimate of the vast area and lake and garden designs to create the 'park city', Putrajaya has targeted targets to make Putrajaya a low carbon city to reduce the intensity of GHG emissions by $50 \%$ compared to 2005 . This target is an extension of Malaysia's target of reducing GHG emissions by $40 \%$ by 2020. One of Putrajaya's Green City 2025 Goals is to make green cities and green neighbourhood.

\section{ii. The State of Selangor}

Selangor is located in the west of Malaysia with covered area of approximately $7,930 \mathrm{~km} 2$. The state of Selangor has nine (9) districts. The population in Selangor state in 2018 to 2019 with an estimated of 5.46 million people. Selangor has grown rapidly from every aspect of development. Selangor's state contribution is also seen as the growth rate of the country's development known as the home of economic power. In addition, residents in the state of Selangor enjoy a high standard of living with comprehensive infrastructure and facilities provided. In fact, Selangor has some very distinctive developments in 13 other countries in Malaysia. Hezri AA, Hasan MN. (2004) stated that Selangor is a rapidly developing state in terms of socio-economic, economic structure and environmental impact. Selangor is also the first state to take steps to develop a sustainability approach by incorporating a comprehensive strategy for sustainability development, policy and policy development programs at all levels of governance. Selangor has also incorporated a vision and sustainable development action for socio-economic, environmental and economic well-being. In addition, Selangor also took proactive steps in implementing their sustainable development into their local, global and national development process. Undoubtedly, the state of Selangor is a state that has been active in pursuing sustainable development and their socioeconomic development towards green neighbourhood elements.

\section{iii. The Iskandar Malaysia, Johor}

Ho WS, Hashim H, Lim JS. (2014) states that Iskandar Malaysia is located in the southern part of Malaysia's peninsula in Johor. Iskandar Malaysia has a population of 1.8 million people. The area of Iskandar Malaysia is about 2,216.3 km2 (221,634 hectares). Five local planning authorities under the Iskandar Territory are from five local authorities namely the Johor Bahru City Council, the Pasir Gudang Municipal Council, the Kulaijaya Municipal Council, the Johor Bahru Central Council and part of the Pontian District Council. Referring to Iskandar Malaysia (2019), this area has a sustainable development strategy of the Comprehensive Development Plan (CDP). In the success of the CDP, solid collaboration from communities, governments, agencies at all levels. Following the CDP, Iskandar Malaysia has also implement several programs and action plans such as the Low Carbon Society (LCS). Through LCS, it employs development for social, economic and environmental.

\section{E. Stakeholders/Partnership in Green Neighbourhoods} Initiatives

Referring to implement this green neighborhood initiative requires a wide-ranging commitment from parties such as Local Authorities, state governments, developers, stakeholders and communities. In the success of this plan requires a creative approach because it involves the provision of facilities to the public. Local authorities need to be aware and ready to provide the best service to the public and at the same time require the provision of green neighborhood elements in urban development planning. Ibrahim Ngah, Zulkifli AS. (2014) states that in a development there are different ways in which social and organizational arrangement. Referring to Asan \& Ashim, (2005), collaboration with related organizations and agencies can enhance the success of a development, especially Local Planning Authorities, government and nongovernment agencies. The apotheosis between the Local Authorities and other agencies as well as statutory bodies such as the Malaysian Green Technology Corporation, Malaysian Institute of Planners, local and foreign universities. According to Abdul Halim A, Mohammad Sukeri K, Yusuf P. (2013), stakeholder engagement and cooperation in providing ideas for environmental management planning towards sustainable development.

\section{F. Differences between Common Neighbourhoods and Green Neighbourhood Initiatives}

Since the Ministry of Urban Wellbeing, housing and local government introduced this initiative, it has become increasingly popular in urban areas, especially in areas with housing. Initially the concept is only beginning from the concern of the urban and community life. The effort to develop green neighbourhood facilities and initiatives is to provide the best services to the community. In addition, people can interact with each other. 
International Conference on Recents Advancements in Engineering and Technology (ICRAET-18) |15th and 16th March 2019|Siddhartha Institute of Technology \& Sciences, Telangana, India.

Table 1. Differences between common neighbourhoods and green neighbourhoods

\begin{tabular}{|c|c|}
\hline $\begin{array}{l}\text { Common } \\
\text { Neighbourhood }\end{array}$ & Green Neighbourhood \\
\hline $\begin{array}{l}\text { Does not apply } \\
\text { environmental friendly in } \\
\text { building, infrastructure } \\
\text { and utilities construction }\end{array}$ & $\begin{array}{l}\text { Apply green elements in } \\
\text { construction for buildings, } \\
\text { infrastructure, utility and built } \\
\text { environment. }\end{array}$ \\
\hline
\end{tabular}

\begin{tabular}{|c|c|}
\hline $\begin{array}{l}\text { Depending on all natural } \\
\text { resources and no energy } \\
\text { savings. }\end{array}$ & $\begin{array}{l}\text { Apply and always practice } \\
\text { energy savings and good } \\
\text { resource management. }\end{array}$ \\
\hline $\begin{array}{l}\text { Communities use private } \\
\text { vehicles, no efficient } \\
\text { public transport facilities } \\
\text { and no transportation } \\
\text { facilities integration }\end{array}$ & $\begin{array}{l}\text { Apply the concept of transit- } \\
\text { oriented development, } \\
\text { integration } \\
\text { transportation public } \\
\text { Connectivity, mode. } \\
\text { walkability \& narrower streets. }\end{array}$ \\
\hline $\begin{array}{l}\text { Uncontrolled } \\
\text { development, no green } \\
\text { element and encouraging } \\
\text { sprawl. }\end{array}$ & $\begin{array}{l}\text { Development practices } \\
\text { conserve land and energy- } \\
\text { saving and resources saving. }\end{array}$ \\
\hline
\end{tabular}

Source: PLANMalaysia (2012)
Table 1 indicating the differences between common neighbourhoods and green neighbourhoods in Malaysia. Green neighbourhood apply the green approaches in buildings, infrastructures, practice efficient, transit-oriented development and to conserve land and energy resources.

\section{G. Singapore's Green Plan 2015 as a Benchmark}

According to Singapore's Green Plan 2015, they dedicated to saving the future with environmental friendly for carbon emissions reduction, the well-being improvement and happiness of its citizens and visitors. The local government wants to improve on the air quality, effective and clean transport, sustainable resources, higher community workers, minimum wastage, preservation of nature resources, planting new trees and building more green lung and parks. Ministry of Water and Environment Resources was proposed Singapore's Green Plan 2015 in 1992 and was updated in 2012 in order to make Singapore to be an environmentally friendly city, whilst ensuring sustainability is met both globally and locally.

Table 2. List of Actions and Programs in Singapore's Green Plan 2015 - Budget 2019

\begin{tabular}{|c|c|c|c|}
\hline No & Policies & Green Action/Program & 5 Green Neighbourhood \\
\hline 1 & $\begin{array}{l}\text { Preserving \& Increasing } \\
\text { Green Areas }\end{array}$ & $\begin{array}{l}\text { Population of trees \& plants land space } \\
\text { for nature reserves \& parks. }\end{array}$ & \\
\hline 2 & Sky Rise Greenery & $\begin{array}{ll}\text { - } & \text { Walking around a gigantic garden. } \\
\text { - } & \text { Nature Relationship } \\
\text { - } & \text { Cleaner air. }\end{array}$ & Pedestrian Walkway \\
\hline 3 & Public Housing Estates & $\begin{array}{l}\text { - } \quad \text { Car-free town centre. } \\
\text { - } \quad \text { Community garden. } \\
\text { - } \quad 20 \text { ha central park. }\end{array}$ & $\begin{array}{l}\text {-Pedestrian Walkway } \\
\text {-Community Farming }\end{array}$ \\
\hline \multirow[t]{4}{*}{4.} & \multirow[t]{4}{*}{ Sustainable Resources } & $\begin{array}{ll} & \text { Providing food resources. } \\
\text { - } & \text { Vertical farming into the skies. } \\
\text { - } & \text { Farming for typical land } \\
\end{array}$ & Community Farming \\
\hline & & $\begin{array}{l}\text { - Organic waste is recycled and } \\
\text { composted }\end{array}$ & Waste Composting \\
\hline & & $\begin{array}{l}\text { - } \quad \text { Provides water and collects rainwater by } \\
\text { system. }\end{array}$ & Rainwater Harvesting System \\
\hline & & $\begin{array}{l}\text { Uses the power only } 60 \text {-watt light bulb } \\
\text { for each tower. }\end{array}$ & \\
\hline 5. & Green Vehicles & $\begin{array}{l}\text { Standard from The National Environment Agency } \\
\text { (NEA) : } \\
\text { - } \quad \text { Diesel vehicles being strict. } \\
\text { Large fines. } \\
\text { Enforcing a cycling scheme. } \\
\text { - } \quad \text { Encourage stop using cars for shorter } \\
\text { distances. }\end{array}$ & $\begin{array}{l}\text {-Pedestrian -Walkway } \\
\text { Bicycle Lane }\end{array}$ \\
\hline 6. & $\begin{array}{l}\text { A Strong Relationship with } \\
\text { the Industrial Sector }\end{array}$ & $\begin{array}{l}\text { Laws on new industrial planning by NEA: } \\
\text { - } \quad \text { Emissions monitoring } \\
\text { - } \quad \text { Environmentally friendly value. } \\
\text { - } \quad \text { Apply the latest green technology. } \\
\text { The government body engages with } \\
\text { industries. }\end{array}$ & \\
\hline
\end{tabular}

Source: Singapore's Green Plan 2015 (2012)

III. METHODOLOGY 
According to Igwenagu (2016), the methodology is a theoretical and systematic analysis of the methods used to conduct a study. It includes theoretical analysis of the methods and principles related to the study. Methodology includes concepts such as paradigms, theoretical models, phases and techniques of obtaining data. Ishak, I.S. (2005) note that this methodology is a guideline for problem solving, with specific components such as methods and tools for planning, reviewing and conducting projects.

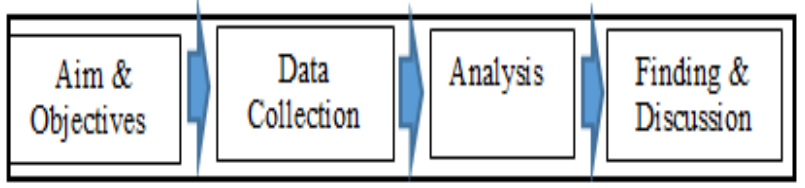

Figure 1. Methodological Framework

Figure 1 indicating the proses of research method which include aim, objectives, data collection, analysis, finding and discussion on the implementation of green neighbourhood initiatives in urban living.

\section{DATA COLLECTION}

This study adopts a method of data collection using a comprehensive study methodology to review tools, action plans, programs and detailed information on the implementation of green neighborhood initiatives in Putrajaya, Selangor and Johor. The information and data collected are through referrals and searches in published magazines, web pages, books, articles, journals and conference papers. The implementation of green neighborhood initiatives was formed by summarizing all programs and actions by Putrajaya, Selangor (SJMC and PJCC) and (Iskandar Malaysia) Johor. Data collection for this study using through record review method integrates with various sources and uses different designs. Smith, Thorpe and Jackson (2015) describe various methods, including collecting data through surveys, observation methods and using existing secondary data.

\section{A. Initiatives of Green Neighbourhood in Putrajaya}

According to Towards Putrajaya Green City 2025 (2013), Putrajaya's efforts to implement all these sustainable action plans and green neighbourhoods are very positive and thriving in line with the vision and effort to achieve the goal of making the city world-class in 2020. The green neighbourhood initiative program in Putra Jaya is a continuing program to become a local authority in involving communities, communities, community-based organizations (CBOs), private sector, non-governmental organizations (NGOs), residents in the city and other stakeholders in carrying out activities and programs according to the wishes and wants of the residents in the area. However, local people are strongly encouraged to take part in programs implemented to mitigate or address specific issues and problems and achieve mutual consent in their respective areas. These measures can also improve management in terms of their environmental quality. These actions and programs formed by the Putrajaya Corporation in the implementation of green neighbourhood initiatives and Green City initiatives with Towards Putrajaya Green City 2025 (PGC2025).
Table 3. List of Actions and Programs in Towards Putrajaya Green City 2025

\begin{tabular}{|c|c|c|}
\hline No & Actions/Programs & Themes \\
\hline 1. & $\begin{array}{l}\text { Management \& planning of integrated } \\
\text { city }\end{array}$ & \multirow{6}{*}{$\begin{array}{l}\text { Low Carbon } \\
\text { Putrajaya }\end{array}$} \\
\hline 2. & Transport have to be carbon low & \\
\hline 3. & $\begin{array}{l}\text { Buildings have to be cutting-edge } \\
\text { sustainable }\end{array}$ & \\
\hline 4. & Lifestyle have to be carbon low & \\
\hline 5. & Have more energy renewable & \\
\hline 6. & Green's lung Putrajaya & \\
\hline 7 & Building \& structure of cooler urban. & \multirow{2}{*}{$\begin{array}{l}\text { Cooler } \\
\text { Putrajaya }\end{array}$} \\
\hline 8. & $\begin{array}{l}\text { The temperature will reduce by } \\
\text { individual \& community }\end{array}$ & \\
\hline 9. & Use less and consume less & \multirow{3}{*}{ 3R Putrajaya } \\
\hline 10. & You throw after you think & \\
\hline 11. & Integrated waste treatment & \\
\hline 12. & Green incentive and capacity building & General \\
\hline
\end{tabular}

Source: Towards Putrajaya Green City 2025 (2013)

Table 3 indicating list of action plans and programs in Putrajaya Green City 2025. From this action, Putrajaya Corporation implementing this element of green neighbourhood initiatives in their development. PGC2025 is a research and collaborative study from Putrajaya Corporation, Okayama University Japan, Universiti Teknologi Malaysia, Malaysian Green Technology Corporation and Kyoto University Japan since year 2010. The main point of actions to reduce carbon emission and implementing green neighbourhood initiatives.

\section{B. Initiatives of Green Neighbourhood in Selangor}

The State of Selangor has provided a high level of cooperation in implementing a state towards sustainable development by forming a green action plan as a state government effort to support implementation to realize green neighbourhood initiatives. Municipal councils and city councils in the state of Selangor have been implementing and practicing green cities by incorporating elements of green neighbourhood initiatives in their respective green action plan elements. However, the discussion in this paper only selects two local authorities in the State of Selangor namely the Subang Jaya Municipal Council (SJMC) and the Petaling Jaya City Council (PJCC). These Local Authorities have been selected in this paper as they are among the active and continuing Council implementing green urban living and green neighbourhood elements in Selangor.

\section{a. Subang Jaya Municipal Council}

The total population with an estimated of 718,629 people and the administrative area of SJMC is $70.41 \mathrm{~km} 2(16,180$ hectares). Referring to Subang Jaya Greenest City Action Plan 2030 (2016), the sustainable development to reduce carbon footprint was created in the SJMC for improvement of social, economic and physical development. Subang Jaya Greenest City Action Plan 2030 is the documentation for the Green City initiatives that has to be carried out for SJMC to become the Greenest City by 2030. The Subang Jaya Greenest City Action Plan 2030 is a collaboration between 
research institutions from Universiti Pertanian Malaysia, Malaysian Institute of Planner and Malaysian Green Technology Corporation. The report consist of the ten goals to be achieved for the Green City initiative with the proposed short term, mid-term and long term strategy. In order to consolidate the green neighbourhood implementation, it outlines 10 goals and actions to reduce carbon emission and to implement green neighbourhood initiative in urban living.

Table 4. List of Actions and Programs in Subang Jaya Greenest City Action Plan 2030 Action/Program

\begin{tabular}{|c|c|c|}
\hline No & $\underline{\text { Action/Program }}$ & Goal \\
\hline 1. & To secure MPSJ's international reputation known for its green enterprise. & Goal 1 \\
\hline 2. & Fossil fuels have to be eliminated dependence & Goal 2 \\
\hline 3. & $\begin{array}{l}\text { Lead the world in green building construction and design of building to lead the world } \\
\text { in green. }\end{array}$ & Goal 3 \\
\hline 4. & The preferred transit options should be walking and cycling & Goal 4 \\
\hline 5. & Zero waste have to be created. & Goal 5 \\
\hline 6. & $\begin{array}{l}\text { MPSJ's residents enjoy incomparable access to green spaces, including the world's } \\
\text { most spectacular urban forest. }\end{array}$ & Goal 6 \\
\hline 7. & Achieve a one planet ecological footprint. & Goal 7 \\
\hline 8. & Drinking water in MPSJ is best in the world. & Goal 8 \\
\hline 9. & MPSJ want to have cleanest breathe air in the world. & Goal 9 \\
\hline 10. & Urban food systems could become as a leader in MPSJ. & Goal 10 \\
\hline
\end{tabular}

Source: Subang Jaya Greenest City Action Plan 2030 (2016)

\section{b. Petaling Jaya City Council}

The total population with an estimated of 619,925 people and the administrative area of PJCC is $97.2 \mathrm{~km} 2$. According to Petaling Jaya City Council Low Carbon City Action Plan 2015-2030 (2015), in 2014 PJCC worked with Carbon Trust UK to identify the carbon footprint of their own estate and ways in which they can reduce it. From this PJCC set an ambitious target to reduce that footprint by $25 \%$ by 2020 . This is underpinned by robust technical analysis and well developed methods and technologies. PJCC have now developed a city carbon action plan through to 2030. This action commits the city to a target of reducing $\mathrm{C} 02$ by $30 \%$ by 2030 against business as usual. The carbon trust is proud to support PJCC in their on-going carbon management efforts and city climate planning. Community and Local Authorities at the PJCC Council are committed to involve and participate in implementing green neighbourhood initiatives to form a harmonious, comfortable, organized, neat, accessible, safe and peaceful city. The Petaling Jaya City Council has established three committees namely the Social Committee, the Environment Committee and the Security Committee to develop sustainable city and develop a green neighbourhood initiative implementation approach. The committee is set up with the identification of the problems and issues faced by the PJCC in the field of security, community and environment. It outlines 6 goal and actions to reduce carbon emission and green neighbourhood initiative in urban living.

Table 5. List of Actions and Program by PJCC Low Carbon City Action Plan 2015-2030

\begin{tabular}{lll}
\hline No & Action/Program & Goal \\
\hline 1. & Building and energy & Goal 1 \\
\hline 2. & Transportation & Goal 2 \\
\hline 3. & Waste management & Goal 3 \\
\hline 4. & Urban forestry & Goal 2 \\
\hline 5. & Climate change adaptation & Goal 5 \\
\hline 6. & Local government operations & Goal 6 \\
\hline
\end{tabular}

Source: PJCC Low Carbon City Action Plan 2015 - 2030 (2014)

\section{Initiatives of Green Neighbourhood in Iskandar} Malaysia, Johor

Referring to Iskandar Malaysia Low Carbon Society Blueprint 2025 Third Edition (2014), the LCS action plan is an initiative to Iskandar Malaysia and it has a methodology, content, action, measures and programs to respond to calls for reducing greenhouse gases, to eventually create a "strong international metropolis, sustainable international position by $2025 "$. The LCS Blueprint is an action plan for reducing carbon emissions in Iskandar Malaysia. This action plan has also been supported by the Japan International Cooperation Agency (JICA) and Japan's Science and Technology Agency (ANN), the LCS action plan is a collaboration between research institutions from Malaysia and Japan, including Universiti Teknologi Malaysia, Kyoto University, University Okayama and Institute of Environmental Studies of the State. Although it has been designed for Iskandar Malaysia, an action plan derived from a research project on "Development of Low Carbon Society Scenario for the Asian Region", it can also be implemented as an action plan and template for other countries in Asia. This action plan contains 12 actions and measures to reduce carbon emissions and assist in implementing green neighbourhood initiatives.

Table 6. List of Actions and Programs by Iskandar Malaysia Low Carbon Society Blueprint 2025 (Third Edition)

\begin{tabular}{lll}
\hline No & Actions/Programs & $\begin{array}{l}\text { Green } \\
\text { Theme }\end{array}$ \\
\hline 1 & Green transportation integrated & \\
\hline 2 & Green for industry & \\
\hline
\end{tabular}




\begin{tabular}{lll}
\hline 3 & Low carbon for urban governance & Economy \\
\cline { 1 - 2 } 4 & Green construction \& buildings & \\
\cline { 1 - 2 } 5 & $\begin{array}{l}\text { Green energy system \& renewable } \\
\text { energy }\end{array}$ & Community \\
\hline 6 & Lifestyle for low carbon & $\begin{array}{l}\text { Consensus building \& engagement } \\
\text { of community }\end{array}$ \\
\hline 8 & $\begin{array}{l}\text { City design should be liveable, } \\
\text { walkable and safe }\end{array}$ & Environmen \\
\hline 9 & Growth should be smart \\
\hline 10 & $\begin{array}{l}\text { Rural resources \& infrastructure in } \\
\text { and green }\end{array}$ \\
\hline 11 & $\begin{array}{l}\text { Waste management should be be } \\
\text { sustainable }\end{array}$ \\
\hline
\end{tabular}

\section{Environment of clean air}

Source: Iskandar Malaysia Low Carbon Society Blueprint 2025, Third Edition (2014)

\section{ANALYSIS}

Analytical techniques for this paper was done with review of record analysis using list of green city action plans to gather the detailed information about the green neighbourhood initiatives in Putrajaya, Selangor (SJMC and PJCC) and Johor (Iskandar Malaysia). The analytical techniques with the main nodes and action plans used are elements of green neighbourhood initiatives, list of programs and actions by Local Authority and stakeholder involve within the urban living.

Table 7. List of Green Neighbourhood Initiatives in Action Plans by Local Authorities

\begin{tabular}{|c|c|c|c|c|}
\hline $\begin{array}{l}\text { Green Neighbour } \\
\text { hood } \\
\text { Initiatives }\end{array}$ & $\begin{array}{l}\text { Putrajaya Corpo } \\
\text { ration }\end{array}$ & $\begin{array}{lr}\text { Subang } & \text { Jaya } \\
\text { Municipal } & \text { Council } \\
\text { (SJMC) } & \\
\end{array}$ & $\begin{array}{l}\text { Petaling Jaya } \\
\text { Council } \\
\text { (PJCC) }\end{array}$ & Iskandar Malaysia \\
\hline Pedestrian Walkway & $\begin{array}{l}\text { Low } \\
\text { transport }\end{array}$ & $\begin{array}{l}\text { Walking, cycling and } \\
\text { public transit }\end{array}$ & Transportati-on & $\begin{array}{l}\text { Walkable, safe, livable city } \\
\text { and design }\end{array}$ \\
\hline Bicycle Lane & $\begin{array}{l}\text { Low } \\
\text { transport }\end{array}$ & $\begin{array}{l}\text { Walking, cycling and } \\
\text { public transit }\end{array}$ & Transportati-on & $\begin{array}{l}\text { Walkable, safe and livable } \\
\text { city design }\end{array}$ \\
\hline $\begin{array}{l}\text { Rainwater harvesting } \\
\text { system }\end{array}$ & Low carbon lifestyle & $\begin{array}{l}\text { Green building } \\
\text { constructi-on. }\end{array}$ & Building \& Energy & $\begin{array}{l}\text { Green buildings and } \\
\text { construction }\end{array}$ \\
\hline Waste composting & $\begin{array}{l}\text { Integrated } \\
\text { treatment }\end{array}$ & Create zero waste & Waste Management & $\begin{array}{l}\text { Sustainable } \\
\text { management }\end{array}$ \\
\hline Community Farming & Low carbon lifestyle & urban food systems & $\begin{array}{l}\text { Climate } \\
\text { adaptation }\end{array}$ & Low carbon lifestyle \\
\hline
\end{tabular}

\section{Source: Author (2019)}

Table 7 indicating the list of green neighbourhood initiatives in urban living by four Local Authorities green action plans. This table is shown that Local Authorities in Putrajaya, Selangor (SJMC and PJCC) and Johor (Iskandar Malaysia) implementing for green neighbourhood initiative elements of a green action plan and programs for urban living development.

\section{A. Summary Framework of Green Neighbourhood} Initiatives

From the collections and lists that have been made on the implementation of the green city formed through actions and programs conducted at local authorities, it is possible to summarise that there are some green neighbourhood initiatives taken by local authorities to attract local communities. This initiative is summarized in figure 2 with a green neighbourhood initiative framework.

\begin{tabular}{|l|}
\hline \multicolumn{1}{|c|}{ Action Plan } \\
\hline Pedestrian Walkway \\
- Walking, Cyeling \& \\
Public Transit \\
- Low Carbon Transit. \\
- Traspotation \\
- Walkable, Safe, \\
Livable Citv Desien \\
\hline Bicycle Lane \\
- Walking, Cycling \& \\
Public Transit \\
- Low Carbon Transit. \\
- Transportation \\
- Wallkable, Safe, \\
Livable City Desiga \\
\hline
\end{tabular}

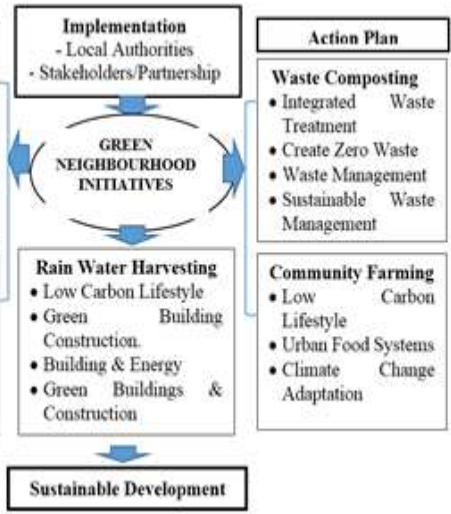

Figure 2. Framework for implementation of Green

Neighbourhood Initiatives formed by the Local Authorities in order to provide sustainable development.

Figure 2 shown that from the action plans and programs taken from a thorough revision study, it is evident that the green neighbourhood initiative has been practiced and implemented in every local authorities. This effort and plan of action is aimed at attracting people and participation in implementing green initiatives. Among the green elements is pedestrian walkway, bicycle lane, rainwater harvesting system, waste composting and community farming.

\section{FINDING AND DISCUSSION}

The Green city action plans and selected green neighbourhood initiatives are a way of forming goals, objectives and visions for the future green neighbourhood and community initiatives. These actions and programs are intended to ensure that communities participate and also get their support to ensure the implementation of this green neighbourhood initiative. Participation of local communities will be able to assist local authorities in measuring progress for the vision of sustainable development agenda. In fact, community participation and the encouragement of local communities by local authorities have been practiced in activities taken in many organisations for achieving high sustainability level. 
The local community will participate in a program with this effort that has been expanded and has a broader perspective towards the importance of an agenda that has significant contributions to their quality of life. Programs and actions that are formed comprehensively can give interest to the community to participate and show their involvement. These programs and actions can also assist local authorities and other agencies to provide elements of green neighbourhood for the local community. This green action plans and programs for knowledge and experiences can make better decisions in the future. The overall review of the records from the program and action plan is to gather detailed information on green neighbourhood initiatives in Putrajaya, Selangor and Johor. In addition, it can be seen that local authorities have very effective programs and actions to implement this initiative.

\section{CONCLUSION}

The support and effort from various stakeholders such as Government, Non-Government Organization, committee, communities and the Council has made. The green neighbourhood initiatives program in Selangor, Putrajaya and Johor successfully implemented with the comprehensive action plans and programs for each Local Authorities and States. The support and high commitment from various stakeholders, communities, Local Authorities, State, NGO and other agencies for green neighbourhood and green city plans also contribute for successfully implemented. The used list of action and program techniques or policies of development such as green transportation, green economy and green communities had assisted in establishing development for green neighbourhood initiatives. It is also assisting in contributing tools and ideas for the green action plan developments in that area. The green elements such as pedestrian walkway, bicycle lane, rainwater harvesting, waste composting and community farming had given a significant impact to the communities. It is because the green neighbourhood gives them action and knowledge on the importance of environment preservation and the effect of their current activities and for the future generation. All of these actions is hopefully will gives inspiration and guidance to other Local Authorities and states in implementing the green neighbourhood initiatives. The green neighbourhood initiatives adopted in the state and city would contribute to the development and sustainability in the aspects of economy, social and environment. The implementation of green neighbourhood stage by stage throughout the nation in Malaysia, this can help to create the awareness among Malaysian and at the same time will helps to develop an environmental responsive nation. Approach from stakeholders, Local Authorities and residents with implementation of green neighbourhood initiatives will increase the quality for communities, economy and environment.

\section{ACKNOWLEDGMENT}

The authors would like to acknowledge the support provided by Universiti Teknologi MARA (UiTM), PLANMalaysia, Subang Jaya Municipal Council during this study.

\section{REFERENCES}

1. Abdul Halim A, Mohammad Sukeri K, Yusuf P. (2013). Ke Arah Pembangunan Mampan Setempat: Pelaksanaan Local Agenda 21 oleh Pihak Berkuasa Tempatan di Malaysia. Jurnal Pendidikan Sains Sosial Dan Kemanusiaan. 6(2): 209-222.

2. Asan, M. O. H. D. N. O. H., \& Ashim, H. A. S. A. H. (2005). Refocusing Development Towards Sustainability - The Case of Selangor , Malaysia The Bruntland Commission articulated the concept of sustainable development as it is known today in 1987 . In this concept, equity, growth equity, integrated with elements of environmental protection. The United Nations Conference on Environment and Development held in Rio de Janeiro in 1992 ( UNCED ) brought about the first global agreement on into the 21 st Century . The progress of implementing Agenda 21 was August- 4 September 2002 in Johannesburg, South Africa ., 6, 125-135.

3. Dahlia Rosly, Nor Zaliza Mohd Puzi, Muhamad Ridzuan Arshad (2013). Planning Strategies, Guidelines And Action Plan For Green Neighbourhoods In Malaysia. (Malaysia : PLANMalaysia).

4. Economic Planning Unit. (2015). Strengthening Infrastructure to Support Economic Expansion. Rancangan Malaysia Kesebelas (Eleventh Malaysia Plan): 2016-2020. Retrieved from http://rmk11.epu.gov.my/book/eng/ EleventMalaysiaPlan/RMKe-11 Book.pdf

5. Faridah Shafii, Zainab Arman Ali, Mohamed Zahry Othman. (2006). Achieving Sustainable Construction in The Developing Countries of Southeast Asia Proceedings of the 6th Asia-Pacific Structural Engineering and Construction Conference (APSEC 2006), 5 - 6 September 2006, Kuala Lumpur, Malaysia. C29-C44.

6. Ho WS, Hashim H, Lim JS. (2014). Integrated Biomass And Solar Town Concept For A Smart Eco-Village In Iskandar Malaysia (IM). Renewable Energy. 69, 190201.

7. Igwenagu, C. (2016). Fundamentals of Research Methodology and Data Collection, Nigeria: LAP Lambert Academic Publishing.

8. Ishak, I.S. (2005). Information Systems Planning Methodology for Malaysian Institute of Higher Learning (ISP-IPTA). International Association for Computer Information Systems, VI (Information Systems Planning Methodology for Malaysian Institute of Higher Learning (ISP-IPTA)), 325-331.

9. In, A., Lumpur, K., Bahru, J., Abidin, N. I., Zakaria, R., Aminuddin, E., Bandi, M. (2016). Article Malaysia' S Local Age Nda 21 : Implementation and, 7, 554-562.

10. Ibrahim Ngah, Zulkifli AS. (2014). Participatory Approach in Planning for Low Carbon and Eco-Village: A case of Felda Taib Andak. International Symposium of the Digital Earth. 1-6.

11. Iskandar Malaysia (2019). Development Plan. Retrieved From Http://Iskandarmalaysia. com.my/OurDevelopmentplan

12. Iskandar Malaysia Low Carbon Society Blueprint 2025 Third Edition (2014). Malaysia

13. Ismail, R. and Saat, S.A., 2004. Engendering environmental political awareness for supporting the sustainable development agenda: a contribution of local authorities in Terengganu, Malaysian Journal of Social Administration, 3(1), pp.39-52. 
14. Ministry of Urban Wellbeing, Housing and Local Government (2012). Green Neighbourhood Development Action Plan. (Malaysia : PLANMalaysia).

15. Malaysian Plan (2006). Ninth Malaysian Plan 2006 2010. Speech by the Prime Minister in the Dewan Rakyat. Government of Malaysia. The Economic Planning Unit, Prime Ministers Department, Putrajaya. Retrieved

From http://www.parlimen.gov.my/news/engucapan_rmk9.pdf and http://www.epu.jpm.my/rm9/html/english.htm

16. Ministry of Water and Environment Resources. Retrieved From https://www.mewr.gov.sg/grab-ourresearch /singapore-green-plan-2012

17. Petaling Jaya City Council Low Carbon City Action Plan 2015-2030 (2015). Malaysia.

18. PLANMalaysia (2012) Garis Panduan Perancangan Kejiranan Hijau: Bahagian Penyelidikan dan Pembangunan. (Malaysia : PLANMalaysia).

19. Prime Minister Department (2006). Ninth Malaysia Plan 2006 - 2010. Malaysia.

20. Profile on Sustainable Development: Malaysia (1997). Information Provided by the Government of Malaysia to the United Nations Commission on Sustainable Development Fifth Session, 7-25 April 1997, New York. Retrieved

From http://www.un.org/jsummit/html/prep_process/national_r eports/malaysia natl_assess.pdf

21. Sabeen Qureshi1 And Ho Chin Siong2 (2011). Towards Putrajaya Green City 2025 Implementing Neighbourhood Walkability In Putrajaya. APSA Congress. 1-7-4 Towards Putrajaya Green City 2025 Planning Strategy for Sustainability, 409-420.

22. SDG Index Report (2018). Gobal Responsibilities Implementing the Goals: Bertelsmann Stiftung and Sustainable Development Solutions Network. Retrieved From http://bit.ly/2uI6itG assess.pdf

23. Sustainable and Local Agenda 21 Unit (2019) Town Planning Department, Subang Jaya Municipal Council. (Malaysia : Selangor).

24. Singapore's Green Plan 2015. Retrieved From https://getecoqube.com/blogs/blog/green-initiatives-insingapore-policies

25. Smith, Thorpe and Jackson (2015). Management Research : $5^{\text {th }}$ Edition (Great Britain : Sage Publication Ltd).

26. Subang Jaya Greenest City Action Plan 2030 (2016). (Subang Jaya Municipal Council : Malaysia).

27. Towards Putrajaya Green City 2025 (2013). First Edition. Putrajaya Corporation Malaysia.

28. The World Bank. (2019). Solid Waste Management. Understanding Poverty [Online]. Available at http://www.worldbank.org/en/topic/urbandevelopment/br ief/solid-waste-management [Accessed on 28 May 2019]

29. Wahi, N., Mohamad, I., \& Zin, R. M. (2018). The High Rise Low Cost Housing: Sustainable Neighbourhood Elements ( Green Elements ) in The High Rise Low Cost Housing: Sustainable Neighbourhood Elements ( Green Elements ) in Malaysia. https://doi.org/10.1088/1757899X/341/1/012028

30. Zakaria, R., Vikneswaran, M., Said, M. I. M., Saleh, A. L., \& Mushairry, M. 2012. Sustainable Neighbourhood Planning and Design in Malaysian Perspective. Applied Mechanics and Materials, 209-211, 1690-1693. https://doi.org/10.4028/www.scientific.net/amm.209$\underline{211.169}$

\section{AUTHORS PROFILE}

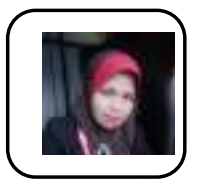

Name : Rohana Ramli

Email : rohanaramliuitm@gmail.com

Phone : 018-2914970

Status : PhD Student in Built Environment

Address : Depatment in Town and Regional Planning,

Faculty of Architecture, Planning \& Surveying, Universiti Teknologi

MARA (UiTM), Shah Alam, Malaysia.

Qualification :

-Master Of Science In Urban Development And Management , UiTM

Shah Alam (2014).

- Bachelor of Town and Regional Planning, UiTM Shah Alam (2007)

-Diploma in Town and Regional Planning, UiTM Shah Alam (1992)

-Certificate in Town and RegionalPlanning, UiTM Shah Alam (1990)

Professional Membership:

1. Graduate Member Malaysian Institute of Planners.

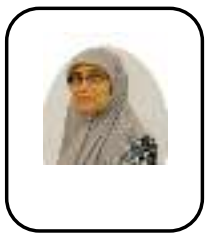

Name : Dasimah Omar

Email ; dasimaho@yahoo.com

Phone : 013-9144491

Status : Lecturer

Professor of Urban and Regional Planning At University Technology Of Mara

Address : Depatment in Town and Regional

Planning, Faculty of Architecture, Planning \& Surveying, Universiti

Teknologi MARA, Shah Alam, Malaysia.

Qualification :

-PhD (Town \& Regional Planning) UiTM Shah Alam (2002)

-MSc. in Urban Development University of Strathclyde, UK (1990)

-Diploma Translation (DBP-PPM) (1987) Advanced Diploma in Town

and Regional Planning Institute Teknologi MARA Shah Alam (1979)

-Diploma in Town and Regional Planning Institut Teknologi MARA

Shah Alam (1977)

Professional Membership :

1. Corporate Member Malaysian Institute of Planners (185/87).

2. Registered Town Planner Malaysian Board of Planners (A 185).

3. Member Malaysian Social Impact Assessment (MSIA 016).

PUBLICATIONS Articles in Journal/Chapter in Books/Books/Reviewing

1. Dasimah, O., Zaharah, M. Y., Saberi, O., Kamaludin, Z., \& Kamarul, A. O. (2017). Recreation Facilities for Youth in Malaysian Urban Areas Case Studies: Lembah Pantai, Kuala Lumpur and Kota Kinabalu, Sabah. Planning Malaysia: Journal of the Malaysian Institute of Planners, vol. 15(2), p. 67-74. ISSN1675-62.

2. Filzani Illia Ibrahim, Dasimah Omar, Nik Hanita Nik Mohamad. (2017). Human Interaction in Urban Spaces: A Quantitative Analysis in Urban Park, Shah Alam, Malaysia, Planning Malaysia: Journal of the Malaysian Institute of Planners, vol. 15(2) (2017), p. 75-84. ISSN1675-62.

3. Kamarul, A. O., Dasimah, O., Zaharah, M. Y., Saberi, O., \& Kamaludin, Z., (2017). The Influence of Physical Environment on Youth Characters. Pertanika Journal of Social Sciences \& Humanities, vol. 25, Jun 2017, p. 35-42.

4. Kamarul, A. O., Saberi, O., Dasimah, O., \& Zaharah, M. Y. (2017). Youth Well-Being Index in the Neighbourhood Space: Outdoor Vs Indoor Space. WIT Transactions on Ecology and the Environment 214, p. 163-171. ISBN978-1-84564-ISSN (print) 113-91746-448X.

5. Ali, I., Omar, D., \& Kamaruddin, S. M. (2016). Climate Change and Freshwater Availability: Present and Future Challenges. Scientific Research Journal, 13(1), p. 26-37. ISSN1675-7009. 6. Shafie, F. A., Omar, D., Karuppannan, S., \& Ismail, N. (2016). Urban-scale Material Flow Analysis: Malaysian Cities Case Study. International Journal of Environment and Sustainability, 5(2), p. 45-53. ISSN1927- 9566. 
International Conference on Recents Advancements in Engineering and Technology (ICRAET-18) |15th and 16th March 2019|Siddhartha Institute of Technology \& Sciences, Telangana, India.

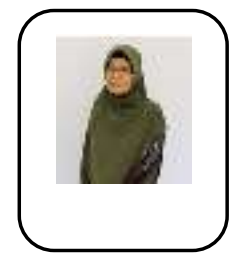

\section{Name ; Puziah Ahmad}

Email : puziah.ahmad114@gmail.com

Phone : : 019-3263213

Status : Lecturer

Address : Depatment in Town and Regional Planning, Faculty of Architecture, Planning \&

Malaysia. Surveying, Universiti Teknologi MARA, Shah Alam,

Qualification :

-PhD (Built Environment) UiTM Shah Alam (2008)

-Master of Planning University of Auckland, New Zealand (1997)

-Bachelor of Town Planning University of New South Wales, Australia (1989)

Professional Membership:

1. Graduate Member Malaysian Institute of Planners.

2. Member of New Zealand Geographical Society (2013).

PUBLICATIONS Articles in Journal/Chapter in Books/Books/Reviewing:

1. A Comparative Requirement of Space Analysis: Green and Open Space Design, CSSR 2017, 4th International Conference on Social Science and Social Research at the Pines Hotel Melaka, 7 Dec 2017. (Main author).

2. The Satisfaction Level of Indigenous People Towards Planned Housing, ICRMBEE 2017, Best Western Hotel I-City Shah Alam, 8 Nov 2017. (Co-author)

3. Low Carbon Campus landscapes at Premier Polytechnic of Sultan Sallehuddin Abdul Aziz, 4th International Conference on Social Science and Social Research CSSR2017, The Pines Hotel Melaka, 7 Dec 2017. (Coauthor).

4. A Review on the Effectiveness of Urban Solid Waste Management in Selangor: A case study of Subang Jaya Municipal Council. BEJ (Built Environment Journal, UiTM Press, p. 17, vol. 14(2), FSPU, 2017. (Coauthor).

5. Green Neighbourhood Adaptive Model for Urban Living: A Conceptual Review, AicQoL2017 Bangkok, Nouvo City Hotel, Bangkok, Thailand, 25-27 Feb 2017. (Main Author). 6. Geo-Heritage Conservation: Content Analysis, AicQoL2017 Bangkok, Nouvo City Hotel, Bangkok, Thailand, 25-27 Feb 2017. (Co-author). 